\title{
We Do Negotiate with Terrorists: Navigating Liberal and Illiberal Norms in Peace Mediation
}

\author{
Julia Palmiano Federer
}

Department of Political Science, University of Basel, Basel, Switzerland/

Swiss Peace Foundation, Bern, Switzerland

julia.palmiano@unibas.ch

This work was supported by the Swiss National Science Foundation.

The author would like to thank Mimmi Söderberg Kovacs, Daniel Finnbogason and three anonymous reviewers for their helpful comments on the text.

No potential conflict of interest was reported by the author.

Julia Palmiano Federer is a PhD Candidate at the University of Basel. Her doctoral research analyses the role of mediators in norms diffusion, specifically in the context of the peace process in Myanmar. She has also published policy papers on international peace mediation, gender, and Myanmar politics. Julia works as a Program Officer in the Mediation program at swisspeace, where she is conducting her doctoral research in the framework of the Swiss National Science Foundation funded project, “Are mediators norm entrepreneurs?” She holds a MA in International Affairs from the Graduate Institute of International and Development Studies in Geneva. 


\title{
We Do Negotiate with Terrorists: Navigating Liberal and Illiberal Norms in Peace Mediation
}

\begin{abstract}
The normative framework in mediation processes is growing. Mediators are increasingly expected by their mandate givers to incorporate liberal norms such as inclusivity into their overall strategy. However, in the wake of the terrorist attacks that took place on 11 September, 2001, and the policy shifts that accompanied the "Global War on Terror," mediators find themselves simultaneously pressured to design mediation processes actively excluding armed groups proscribed as terrorists and consequently incorporating this illiberal norm of “exclusivity,” barring proscribed groups' access to negotiations. This paper asks to what consequences this development has on the normative agency of mediators, based on if and how they incorporate proscribed armed groups into their mediation strategies. This paper argues that the dichotomy between liberal and illiberal norms has important consequences on a mediator's normative agency. Firstly, the dichotomy constrains mediators to a single normative standard, rendering only liberal and illiberal views possible. Secondly, the assumption that liberal norms are "good" and illiberal norms are "bad" engenders a double dichotomy that greatly constrain a mediator's normative agency.
\end{abstract} Thirdly, these constraints in term engender new mediation practices in attempt to salvage normative agency through outsourcing and risk-sharing. This paper contributes to scholarship on norms, terrorism and mediation through providing a more nuanced view of normative parameters in mediation practice.

Keywords: mediation, terrorism, norms, conflict resolution, armed groups, proscription

\section{Introduction}

The normative framework in mediation processes is growing. Mediators ${ }^{1}$ are increasingly expected by their mandate givers to incorporate norms into their overall

1 'Mediators' are defined as third party actors who assist two or more parties, with their consent, to prevent, manage or resolve a conflict by helping them to develop mutually acceptable agreements (United Nations 2012). 
strategy. Apart from being charged with resolving violent conflict, mediators are expected to incorporate norms such as inclusivity ${ }^{2}$ based on liberal notions of equality and human rights into their overall strategy. However, in the wake of 9/11 and the policy shifts that accompanied the "Global War on Terror," mediators find themselves simultaneously pressured to design mediation processes actively excluding proscribed armed groups, and consequently incorporating this illiberal norm excluding armed groups designated as terrorists from access to negotiations and other mediation activities.

This paper examines the normative agency of mediators in mediation processes regarding norms that are perceived as illiberal or liberal. It asks what consequences this illiberal-liberal dichotomy has on the normative agency of mediators, based on if and how they incorporate these norms into their overall mediation strategy. It focuses on two salient norms in mediation processes for mediators: the norm of inclusivity, manifested most prominently as engaging with all relevant groups in a given conflict context; and the norm of exclusivity, manifested in proscription regimes barring armed groups listed as terrorists from access to negotiations.

This question matters for better understanding the role of mediators in promoting certain norms ${ }^{3}$ to other mediators or the negotiating parties themselves. As international peace mediation is an endeavour embedded in the liberal peacebuilding paradigm, conceptual confusion surrounding engaging with proscribed armed groups

${ }^{2}$ The norm of inclusivity is defined in the UN Guidance for Effective Mediation as: "the extent and manner in which the views and needs of the conflict parties and other stakeholders are represented and integrated into the process and outcome of a mediation effort." (United Nations 2012)

${ }^{3}$ The author understands norms as "collective expectations for the proper behaviour of actors with a given identity" (Katzenstein 1997, 5). The identity in question is that of a mediator. 
can result in dichotomies being set up between what is liberal and what is illiberal. This can, in an unfortunately un-nuanced fashion, render mediators either as a liberal or illiberal norm entrepreneur ${ }^{4}$, depending on if and how they incorporate engaging with armed groups into their mediation strategies. The relevance of the question is conceptual and practical in nature. Due to the increasingly complex peacemaking landscape featuring the fragmentation of armed groups and an increasingly heterogeneous array of mediation actors, the categorical ban of speaking to proscribed armed groups no longer characterises reality or practice (Neumann 2007; Powell 2014; ACCORD 2016). As the principle of "speaking to everyone”, or "engaging with all relevant actors” has become a new mantra for modern day mediators (Whitfield 2010; Hapesgelagh 2013; Powell 2014; Guarrigues 2015), the question for mediators has focused rather on the modalities of engaging with proscribed armed groups in practice. Despite this practical development, there is a dearth of research on the normative involvement of third parties writ large, not least on this contested topic (Kastner 2015). The issue of engaging with proscribed armed groups reveals a clashing set of normative frameworks found in peace mediation practice and counter-terrorism policies, and raises questions of how mediators navigate in between them.

This paper argues that the dichotomy between liberal and illiberal norms has important consequences on a mediator's normative agency. Firstly, the dichotomy constrains mediators to a single normative standard, rendering only liberal and illiberal views possible. This dichotomy also creates a host of unhelpful binaries between normative and pragmatist approaches to mediation and buries problematic assumptions

\footnotetext{
${ }^{4}$ This concept is based off of Finnemore and Sikkink's 'life cycle' model of norm diffusion. 'Norm entrepreneurs,' defined as "actors who attempt to convince a critical mass of [actors] to embrace new norms” (Finnemore and Sikkink 1998, 895).
} 
about the primacy of the liberal normative standard in global politics. Secondly, the assumption that liberal norms are "good" and illiberal norms are "bad" engenders a double dichotomy that greatly constrain a mediator's normative agency. For instance, this double dichotomy creates difficult dilemmas for mediators when managing processes where armed groups are labelled terrorists and as spoilers. Thirdly, these constraints in turn engender new mediation practices in attempt to salvage normative agency through outsourcing and risk-sharing. The rise of multi-party mediation and private mediation allows more formal actors to outsource these dilemmas to less formal actors with greater normative room for manoeuvre.

This paper is organised as follows. Firstly, the paper tackles existing literature in international relations scholarship that creates dichotomies between liberal and illiberal norms, and highlights the progressive norm bias in norm diffusion scholarship. Secondly, the paper describes how these dichotomies and biases create a "clash" between the normative frameworks surrounding mediation and counter-terrorism. Thirdly, through an investigation into the normative agency of mediators, the paper shows how the heterogeneity of mediators and the rise of private diplomacy and the burgeoning collaborative practices around engaging with proscribed armed groups render the dichotomy between mediators as liberal or illiberal norm entrepreneurs false. It then illustrates these theoretical arguments through an empirical look at the peace and conflict landscape of the Philippines. ${ }^{5}$

\footnotetext{
${ }^{5}$ From a methodological perspective, this paper draws from academic and policy literature in the fields of peace research and critical studies on terrorism. The empirical illustration from the Philippines context draws from primary documentation on the Philippine peace processes
} 
This paper aims to contribute to research on mediation and norm diffusion in two ways. Firstly, it examines the role of mediators in norm diffusion, addressing research gaps in the respective subfields. Secondly, it challenges the progressive norm bias in norms diffusion scholarship by providing a more nuanced view of the normative parameters in mediation practice.

\section{Norm Diffusion in International Relations: The Good, the Bad, the Liberal and the Illiberal}

In order to understand normative and practical discussions of mediators engaging with armed groups, the paper illustrates how norms can take on a liberal or illiberal connotation by showing the dichotomies and biases created in existing scholarship on norm diffusion.

\subsection{The Progressive Norm Bias in Norm Diffusion Scholarship}

Norm diffusion mechanisms have been central to the study of behaviour and change in international relations theory since the normative turn in social constructivism (Finnemore and Sikkink 1998; Keck and Sikkink 1998; Risse, Ropp and Sikkink 1999). One of the modest prominent models of norm diffusion is Finnemore and Sikkink's (1998) "life cycle model.” This model charts a cycle of norms from emergence, cascade, and internalization (Finnemore and Sikkink 1998) to trickling down in a spiralling manner by means of discursive processes between norm-violating and normpromoting actors (Risse, Ropp and Sikkink 1999). The concept of "norm entrepreneurs" has been particular salient, drawing attention to the agency of transnational and non- 
governmental actors that shape and create norms as norm-makers and convince a critical mass of actors (primarily states) to adopt a given norm through imitation until it obtains a taken for granted quality (Finnemore and Sikkink 1998).

Models of norm diffusion have been engaged with through rich empirical work on a number of norms in different contexts (Tannenwald 1995; Klotz 1995; Nadelmann 1998; Price 1998; Checkel 1998). However, it has also been acknowledged that scholarship has focused on "positive norms”, such as the norms against apartheid, slavery or nuclear weapons (Checkel 1998, 329). Many research designs inherently presuppose positive consequences of norm diffusion of "good” norms based on human rights and other liberal ideals based on the logic of appropriateness, and consequently ignoring the diffusion of norms that "most of us would consider 'bad' - norms about racial superiority, divine right, imperialism - were once powerful because some groups believed in the appropriateness [...] of the norm” (Finnemore and Sikkink, 1998, 892). This bias towards "good” norms was addressed in a shift in social constructivist literature towards a more “dynamic” (Bloomfield 2015) conception of norms and political change. Scholars such as (Payne 2001; Bloomfield, Wiener, Sandholtz; Dietlhoff and Zimmerman etc) hold that norms do not spread in a linear or one-way progressive path, but can regress, erode, decay or die. This new wave of critical, or “reflexive”, “consistent” or "post-positivist” constructivism rejects the notion that norms are fixed (Axelrod 1986?; Ralph 2017; Fierke 2013, Hopf 1998; Welsh 2013; Wiener and Puetter 2009) and posits that norms are contested through a discursive process that repeated constructs different meanings. Norm diffusion models also evolved from linear models to dynamic circuitous models (Acharya 2013) that account for the agency of 'recipient' communities to resist, contest or reject the localization of external norms (Acharya 2004; 2011). 
Despite this large-scale shift in norms literature, the progressive norm bias persists in academic and grey literature on liberal peacebuilding and mediation processes. In the field of peacebuilding and in the growing normative framework of mediation in particular, norms that have diffused in recent years have had a predominantly liberal nature, stemming from the dominance of the liberal peace paradigm. The liberal peace paradigm holds that “certain kinds of (liberally constituted) societies will tend to be more peaceful [...] than illiberal states” (Newman et al. 2009, 11). Different activities related to peacebuilding, ranging from brokering a ceasefire between warring parties to dealing with past atrocities and human rights abuses are increasingly underpinned by "the promotion of democracy, market-based economic reforms and a range of other institutions associated with "modern” states as a driving force for building 'peace”” (3). These activities are designed to broker a just and sustainable peace, well beyond the cessation of hostilities in a given conflict context, and thus involve the spread of liberal norms through the set-up of the basic pillars of a liberal democracy.

The liberal peace paradigm, despite a considerable body of critical scholarship contesting and critiquing its shortcomings (Paris 2002; 2004; 2011; Lidén 2005; Sending 2011; Richmond 2012; Call 2012; Zaum 2012; Campbell et al 2011), has influenced scholarship on norm diffusion in international relations theory. Assuming that liberal norms are inherently positive creates a normative bias that is "progressive" in nature. The liberal peace paradigm, resting on the foundations of a liberal democracy, is problematically conflated with liberalism as a conception of political liberty. As Zakaria points out in his Foreign Affairs’ “The Rise of the Illiberal Democracy,” a liberal democracy is a political system marked by free and fair elections, rule of law, separation of powers, and the protection of basic liberties. A liberal democracy adopts 
the protection of basic rights and liberties as a part of it, even though the protection of rights is better understood as a characteristic of constitutional liberalism. Zakaria argues that constitutional liberalism should be considered both theoretically and historically distinct from a liberal democracy (Zakaria 1997, 22). Similarly, the positive peace paradigm (Galtung 1985) promotes the spread of liberal norms through the set-up of basic pillars of liberal democracy and associates negative peace as the absence of violence. In the liberal peacebuilding paradigm, negative peace is arguably not “enough": society must be redefined and institutions must be set up and basic liberties and human rights, political rights, political rights and property rights must be protected. Positive peace thus becomes strongly associated with setting up pillars of a liberal democracy. Following this logic, the diffusion of "positive” or "good" norms becomes associated with the diffusion of western liberal norms.

\subsection{The Good-Liberal and the Bad-Illiberal Dichotomy}

The need to respond to the "progressive" norm bias creates two dichotomies in norm diffusion scholarship. The first is a tenuous dichotomy between what norms are deemed liberal and what norms are deemed not liberal. Despite a nascent field of scholarship on the nature, actors and mechanisms surrounding illiberal norms on torture (McKeown 2009), targeted killings (Bob 2015); the suppression of LGBTQ rights (xx); whale hunting (xx) and a growing number of illiberal norms (Bob 2012; Checkel 2013; Heller and Kahl 2013; Bloomfield 2015), there is no consensus on what 'illiberal' means. Nonliberal, or "illiberal” norms are not well-defined and are not often used in norms scholarship in international relations. However, inferring from different instances where they are used (Freeman 2001; Bigo et al. 2008; Triadafilopoulos 2011), illiberal norms challenge, suppress or restrict individual liberties and rights. 
The second dichotomy splits liberal and illiberal norms further into two categories (and arguably carries from Galtung’s conception of “negative” and "positive” peace): liberal norms that are inherently "positive” or "good” and consequently, illiberal norms that are inherently “negative” or "bad.” This is evidenced clearly by Heller and Kahl’s (2013) shortcut for the progressive “double-bias” in international relations:

"Past research has not only focused on Western/liberal norm diffusion, but also most of the time has (implicitly) taken side with these norms. As a shortcut for this double bias, we use the term "good" norms when speaking about human rights, and "bad" norms when referring to those ideas that contest them (Heller and Kahl 2013, $414-415)$.

Furthermore, scholarship on norm contestation uses terms like “erosion”, “decay”, “regression” and “death” when good-liberal norms are challenged or contested (Glennon 2005; McKweon 2009; Bloomfield 2015). These terms invoke negative connotations and risk imbuing normative biases regarding how illiberal norms are perceived and treated in norms scholarship.

Why do these dichotomies between good-liberal and bad-illiberal norms matter? Aside from rendering norm diffusion research normative and value-laden, it creates a third dichotomy around norm entrepreneurship: if transnational and non-governmental actors that promote liberal norms such as the protection of human rights and political liberties, rule of law, democratic institutions and peace are good-liberal norm entrepreneurs, are actors that "discursively challenge constitutive and identity-building norms and codes of conduct laid down in international treaties” (Heller and Kahl 2013, 415) therefore bad-illiberal norm entrepreneurs? Illiberal norm entrepreneurship can also be seen as negatively reversing diffusion processes, where these "norm challengers” or “norm revisionists” promote or encourage inconsistent behavior among 
other members of international society among seemingly internalised norms (Bloomfield 2015; Heller and Kahl 2013).

This paper questions these biases and dichotomies and contributes to norm scholarship in two ways. Firstly it does not consider norms a priori positive or negative. It refrains from implicit assumptions of the positive or negative impacts or consequences of norm diffusion or the nature of norms themselves by focusing instead on dynamics of norm diffusion and the contribution of the agent or norm entrepreneur. Secondly, it moves beyond the problematic application of the good-liberal and badilliberal dichotomy to scholarship on norms diffusion by distinguishing not between clashing norms within one normative framework, but clashing normative frameworks in a given sociopolitical process that operates in multiple frameworks.

\section{The Normative Frameworks of Counter-Terrorism and Peace Mediation}

In order to meaningfully link the above discussions on norm diffusion to the mediation, the paper describes how these dichotomies and biases create the 'clash' between the normative frameworks surrounding mediation and counter-terrorism. Each normative framework have their own set of moral norms and procedural principles: the normative framework of counter-terrorism espouses exclusivity, which is manifested in the procedural and legal norm of proscription. In contrast, the normative framework of mediation promotes inclusivity, which is manifested in the mediation logic of engaging with all relevant actors, no matter how "unsavoury" (Zartman xx) they may be. In this section, I juxtapose proscription with engagement.

Proscription means "the act of listing an armed group as a terrorist organization" (Haspeslagh 2013, 189). The impact of proscription on third parties engaging with armed groups in the context of a mediation process has been well-documented in a 
growing set of academic and policy debates (Toros 2008; Dudouét 2010; Sullivan and Hayes 2010; Haspeslagh 2013; Boon-Kuo et al. 2015) in the wake of the "Global War on Terror” precipitated by the events of September 11, 2001. The debate on whether or not to engage with proscribed armed groups in peace processes is not new. Many governments have uttered the categorical ban, “we don’t negotiate with terrorists” (Toros 2008) yet in practice, there are many examples of third party actors ranging from United Nations (UN) envoys, state representatives, and non-governmental organizations engaging to various degrees of discretion with illegal or proscribed actors. Powell (2014) makes an impassioned case on political actors’ collective amnesia on how engaging with proscribed actors is nothing new and has been done throughout history. Mediators' engagement with the Irish Republican Army in Northern Ireland; the UN's engagement with the Farabundo Martí National Liberation Front in El Salvador; the Quartet, Norway and Switzerland's engagement with Hamas; or the government of Colombia’s engagement with the Revolutionary Armed Forces of Colombia (Whitfield 2010) are just some examples that debunk this rhetoric.

Among this growing body of predominantly grey literature mostly borne out of the proceedings and observations from discreet workshops and interviews done with mediators themselves, there is growing “mediator's mantra” that the proscription regime based on the normative framework of counter-terrorism is "antithetical to key norms of conflict transformation” (Boon-Kuo et al. 2015, 33). The normative clash between these two frameworks are manifested in the clash between two norms in particular: the norm of exclusivity in the counter-terrorism normative framework and the norm of inclusivity in the mediation normative framework. More specifically, the exclusionary norms of isolation, disruption, stigmatization and de-legitimization (Boon-Kuo et al. 2015) in the act of proscription is viewed as diametrically opposed to a key process-related norm of 
engagement (with all relevant actors in mediation) that has recently diffused among mediation practitioners and policy makers (Paffenholz 2004; von Burg 2015;

Hellmüller, Palmiano Federer, and Zeller 2015). Pertaining to the exclusion or inclusion of proscribed armed groups in a mediation process, one may observe that characteristics of the counter-terrorism normative framework are illiberal while the characteristics of mediation are liberal. Further reasoning follows below.

\subsection{An Illiberal Normative Framework: Proscription Regimes in the Counter-Terrorism Normative Framework}

The critiques surrounding the application of proscription and the dangers around the lack of consensus around a definition for terrorism, the problematic "outsourcing definitions of terrorism to states” (Muller 2008, 115) and the lack of clarity surrounding who is a terrorist are beyond the scope of this paper. However, in the arena of mediation $^{6}$, proscription regimes are viewed as illiberal for three reasons.

Firstly, proscription regimes are seen as illiberal firstly because they challenge, suppress or restrict individual liberties and rights, specifically those of proscribed groups.

Scholars looking at counter-terrorism and conflict resolution in tandem cite the criticism of lawyers, human rights groups, and civil society organizations for proscription policies that exhibit "potential unconstitutionality, as their imposition may violate the rights to association and free speech as well as due process” (Dudouét 2011, 5). A lengthy legal critique of proscription or blacklisting by Sullivan and Hayes outline key fundamental human rights provisions that are engaged and often violated by the terrorism blacklisting regimes" (Sullivan and Hayes 2010, 26). These provisions include

\footnotetext{
${ }^{6}$ As well as conflict transformation and peacebuilding more broadly. However, this paper focuses specifically on peace mediation.
} 
the right to a fair trial, important as a pre-requisite for enabling proscribed entities to contest the violation of their other human rights; the right to be heard, requiring designated authorities to notify blacklisted individuals of evidence against them, the right to be informed, which enables proscribed individuals and groups to access relevant, incriminating information underpinning their blacklisting, and the right to judicial review/the right to effective remedy (Sullivan and Hayes 2010, 26-31). The report also argues that proscription's asset-freezing measures also directly interfere with the property of rights of those blacklisted. Lastly, Muller (2008) makes a case that proscription regimes can even violate the Jus Cogens norm of self-determination (UN International Covenant on Economic, Social and Cultural Rights) as the practice fails to resolve the relationship between international legal principles such as the right to selfdetermination, the emerging right to democracy, and the existence of a license to use force as a last resort against an oppressive regime (111).”

Second, proscription is perceived as exclusionary as it criminalises the engagement of third party mediators to proscribed armed groups, and consequently preventing access and entry points into peace negotiations. Mason (2009) states that numerous peace mediators have been arrested or jailed for meeting with groups proscribed as terrorists, while under US Foreign Terrorist Organization (US FTO) regulations, “material support” may also mean providing training, workshops or similar activities - running a particular risk for conflict resolution nongovernmental organizations (NGO) and epistemic communities on mediation, as they do not possess diplomatic immunity (Dudouét 2011).

Third, proscription is seen as illiberal because it is often referred to as a contradiction when under-taken by established liberal democracies. Proscription regimes are often the topic of fascination by counter-terrorism scholars stymied by 
established liberal democracies adopting so-called illiberal norms: "norms in general, and human rights, in particular, are continuously being contested, not least as a consequence of the broad range of measures to counter international terrorism adopted by governmental actors in liberal, consolidated democracies” (Heller and Kahl 2013, 415). Following Zakaria’s argument of liberal democracies demonstrating illiberal practices or following illiberal norms, proscription and other counter-terrorism practices are seen as puzzling paradoxes. When some established democracies that are thought to be leaders in liberal and human rights promotion like the United States or the United Kingdom regress from rule-consistent behaviour in their approach to countering terrorism (Heller and Kahl 2013), it is seen as a paradox or contradiction. Proscription by the European Union (EU) or US of political movements with a democratic mandate "stand in sharp normative conflict with these government's democracy promotion efforts (Dudouét 2011, 7).

\subsection{A Liberal Normative Framework: Inclusivity in International Peace}

\section{Mediation}

The UN Guidance for Effective Mediation defines inclusivity as "the extent and manner in which the views and needs of conflict parties and other stakeholders are represented and integrated into the process and outcome of a mediation effort” (United Nations 2012). This norm has become highly relevant both in policy literature and practice, evidenced by the growing number of prescriptive guidelines for mediators when trying to design who gets a seat at the peace table (Lanz 2011; Paffenholz 2014; von Burg 2015). Both policy and academic literature increasingly claim that an inclusive peace process is more likely to address the root causes of conflict, ensure the needs of conflict-affected populations, and increase the legitimacy and national ownership of the peace agreement and its implementation (UN 2012; Lanz 2011; Wanis-St John and Kew 
2008; Zanker 2014). As mediators are understood to wield greater ownership over the design of the process rather than the content of peace agreements, as the ownership of content lies with the negotiating parties ${ }^{7}$, the question of inclusion is contentious and the subject of heated debate in the mediation field (Hellmüller, Palmiano Federer and Zeller 2015).

Inclusivity is often perceived as a liberal norm because of its promotion of political liberties: the freedom of association and speech and the liberal notion of equality. In other words, everyone impacted by the conflict gets a say at the peace table. Inclusivity's roots also rests on the logic of equality embedded in the liberal peacebuilding paradigm. Inclusivity is the embodiment of the pillars of liberal democracy: representative democracy, rule of law, humanitarianism, market-based economic reform and development. These in turn foster respect for individual rights. Inclusivity is often understood and promoted as a norm without making this important distinction.

The reason for so much debate is the vague wording of the UN's definition of inclusivity. Allowing for a large amount of “constructive ambiguity” (see Parlievliet) allows for international agencies and peacebuilding actors to promote inclusivity via a

${ }^{7}$ This process-content distinction is cited widely in mediation literature, see: Bercovitch 1993; $\mathrm{xx}$. The ownership of the parties of the content that eventually constitutes a peace agreement raises important questions about how international norms diffuse into final peace agreement texts. A mediator's role in designing agenda items, supporting single-text draft processes between and among negotiating parties may be an avenue for content-based norms diffusion. This falls slightly outside the scope of this paper but remains a topic of growing scholarly interest: see Hellmüller, Palmiano Federer and Pring 2015; 2017; Bell and O’Rourke xx; Kastner 2015). 
number of different modalities (Paffenholz 2014). For instance, the UN definition creates possibilities between physical and substantive modalities of representation. This has important implications for mediation actors grappling with including proscribed actors at the physical peace tables. This also creates space to host parallel peace processes and consultative mechanisms for non-armed actors to get their views and needs represented in the process. The ambiguity around indirect or direct representation and participation in peace processes creates multiple possibilities for both international and national peacebuilding actors tasked with process design. ${ }^{8}$

This ambiguity can also normative create contention and confusion, specifically which actors should be considered a "relevant stakeholder” (United Nations 2012). Relevance is in the eye of the beholder, or specifically the mediator, who is often faced with the question of selection criteria for peace negotiations. While the inclusivity norm is generally understood to vouch for peace processes that include excluded actors, who these actors actually are can be interpreted in multiple ways. For instance, inclusivity can refer to the inclusion of civil society actors, women leaders and women's groups that have been excluded from traditional and discrete peace talks because they do not hold arms. Inclusivity can also refer the engagement with or the inclusion of actors that have been indicted by the International Criminal Court, sanctioned, or proscribed a terrorists (UN 2012) in a given peace process. The importance of engaging with armed groups is defended among mediation actors and is constantly repeated in both academic and policy literature on mediation theory, process design, and practice (Zartmann 2008;

\footnotetext{
${ }^{8}$ World Development Report 2011, DFID policy guidelines on inclusive political settlements, OECD-DAC and the New Deal, SDG Agenda 16 on inclusive and peaceful societies, etc
} 
Whitfield 2010; Garrigues 2015; Jones 2015). Indeed, “engagement with non-state armed groups is an essential component of any conflict transformation strategy and a key ingredient to a peace agreement’s implementation” (Dudouét 2011), which is more consistent with the pragmatic principle of sufficient inclusion to reduce the chances of the peace process losing legitimacy among key constituencies (Zanker 2014). Many mediators who write about their experiences in debriefings and policy reports also take a form of ownership of their view, based on practice and experience "from a mediator's perspective, engaging with such groups is always worthwhile” (Whitfield 2010; Garrigues 2015, 3).

\section{Are Mediators Liberal or Illiberal Norm Entrepreneurs? Three Consequences on Mediator's Normative Agency}

Observing the increasing pressure on mediators to exclude proscribed armed groups from mediation processes, this paper asks to what extent mediators can be considered liberal or illiberal norm entrepreneurs, based on if and how they incorporate the exclusion of proscribed armed groups into their strategies. This paper argues that the dichotomy between liberal and illiberal norms has consequences on a mediator's normative agency. Firstly, it begets new trends in mediation practice such as multi-party and private mediation that create room for manoeuvre by outsourcing accountability and political risk to less formal actors. Secondly, it creates normative paradoxes for

mediators, as the inclusion of proscribed actors can lead to the exclusion of others.

Thirdly, it lends to binary thinking in peace processes, pitting pragmatist against normative approaches and obfuscating larger critical debates on norms and values in the international system.

Mediators possess normative agency, or the ability to navigate through normative frameworks and promote different norms to other mediators or to the negotiating parties 
themselves. The normative agency of mediators is understood as whether mediators can, or have the agency to, promote norms in the mediation process. In terms of the life cycle model of norm diffusion, the extent to which mediators are norm entrepreneurs depend on how they promote the norm through three phases of norm diffusion: emergence, cascade and internalization. In the norm emergence phase, norm entrepreneurs communicate the issue or norm to their issue to broader audience. In the norm cascade phase, other actors adopt the issue or norm through imitation, manifested in behaviour or policies. In the third and final phase called the norm internalization phase, norms assume a "taken for granted” quality and derogation from said norm must be justified. Within these different phases, Finnemore and Sikkink (1998) distinguish different types of actors 'norm-makers' that they characterise mostly as transnational networks and NGOs often supported by intergovernmental organizations, and "normtakers,” whom they mostly characterise as states.

In understanding norm diffusion in mediation processes, the most relevant entities are mediators, the negotiating parties, and those that mandate or deploy them in a given conflict context (mandate givers). Mediators can be norm entrepreneurs, using their role as a mediator to promote a given norm to the negotiating parties through various activities (ranging from agenda setting to ensuring outside communication with the media). In this vein, the negotiating parties are the norm-takers who start to imitate the behavior and finally internalise certain norms. However, mediators can also be normtakers, since they may imitate other mediators, yet work within the parameters outlined by the distinct normative framework of their mandate givers. In sum, mediators’ normative agency then, refers to their ability to navigate through different normative frameworks depending on their mandate (as a norm-taker) as well as promote norms to 
other mediators or to the negotiating parties themselves, as a norm entrepreneur (Hellmüller, Palmiano Federer, and Pring 2017).

\subsection{Consequence 1: New Mediation Practices that Create Normative Room for Manoeuvre}

Firstly. the dichotomy between liberal and illiberal norms has created new practices among mediation actors that create more room for maneouvre between these clashing normative frameworks. Mediators deal with the liberal-illiberal dichotomy in practice through by outsourcing engaging with proscribed armed groups to actors with normative flexibility through multi-party mediation and private or informal mediation. This allows them to navigate more freely between murky normative frameworks, thereby increasing their normative agency in practice. Mediators are not homogenous in terms of their mandate-givers, and their normative agency depends largely on the parameters outlined by whom they work for. Mason and Sguaitamatti (2011) outline five main types of mandate-givers: the UN, inter-governmental organizations, states, NGOs and organizations headed by eminent individuals. These mandate-givers vary in terms of their normative frameworks and particularly on proscription. ${ }^{9}$

The UN is a crucial mandate-giver, and has mandated mediators in numerous conflicts (Mason and Sguaitamatti 2011, 18-20). Most often, mediators are mandated by the Secretary General as Special Representatives or Special Envoys. The UN’s proscription regime is established through UN Security Council Resolution 1267, 1988, 1989 in relation to the Taliban and Al-Qaeda. They also have a specific sanction regime in the case of Somalia (UN SC/10348, 2011), and UN Security Council Resolution

\footnotetext{
${ }^{9}$ It is important to note that different proscription regimes delineate between engaging with groups and individuals.
} 
1373, 1540 and 1624 require states to take steps against non-state armed groups, including criminalizing terrorism: freezing assets, banning travel, and engaging in an arms embargo against listed entities.

Second, state actors such as the United States (US), Switzerland, Norway and Finland are prominent state actors in mediation, deploying diplomats to engage with parties to conflict in different contexts. These states and others, such as the United Kingdom (UK) and Canada, also support a wide range of mediation and mediation support activities both financially and operationally. Many of these states have proscription regimes. The United States possesses two main lists: the Office of Foreign Assets Control’s Specially Designated and Blocked Persons, and the US State Department's Foreign Terrorist Organizations. Listed entities are subject to freezes and travel bans and under US national law, criminalises "material support or resources" to listed organizations, ranging from money to "training, expert advice and assistance” (US Patriot Act). The UK also has a national law, the Terrorism Act of 2000, which proscribes 48 international organizations and criminalises meeting with groups or assisting in arranging a meeting. Canada’s Anti-Terrorism Act allows its government to list entities under the country’s Criminal Code. In contrast, smaller states such as Switzerland and Norway do not have national proscription lists, but adhere to wider legal parameters, for instance International Humanitarian Law (IHL). ${ }^{10}$

Third, regional and sub-regional organizations have increasingly engaged in mediation since the end of the Cold War. The European Union (EU), the Organization for Security and Cooperation in Europe, and the African Union are examples of regional

\footnotetext{
${ }^{10}$ How IHL is incorporated into domestic law is outside the scope of this paper, but is important to consider when looking at key mediation actors such as Norway and Switzerland.
} 
and sub-regional institutions that mandate mediators. The EU has the most prominent listing regime. The EU's proscription regime is outlined in the EU Common Position 2001/931/CFSP and the EU Council Framework Decision of June 2002. Listed entities on the EU's list are subject to travel bans, visa denials asset freezes, and other financial restrictions.

Fourth, nongovernmental organizations (NGOs) have played active mediation roles in armed conflicts. The large number of international NGOs specializing in mediation and conflict resolution range from specialised institutions such as the Centre for Humanitarian Dialogue (HD Centre), Conciliation Resources, Intermediate, Conciliation Resources; organizations founded by eminent mediators such as former US President Jimmy Carter’s The Carter Center and former Finnish President Maarti Ahtisarri’s Crisis Management Initiative; and faith-based organizations such as Community of Sant'Egidio. These organizations have sent individuals to directly engage with negotiating parties in ongoing peace processes. Due to their relative lack of political power vis-à-vis states, regional organizations, and the UN, nongovernmental mediators often work discreetly behind the scenes and early on in the process. A key comparative advantage for NGOs is their flexibility. However, while they they often work discreetly and in early stages of the process as they do not have lists that ban their engagement, their activities run a greater risk of being criminalised as they do not possess diplomatic immunity (Haspeslagh 2013; Dudouét 2011). Depending on where an NGO is based, they can be subject abiding by the proscription regimes in their home country.

When it comes to normative agency, nongovernmental mediators present a particularly interesting case. Nongovernmental mediators promote the inclusion of excluded armed groups in practice, most specifically through their active and sometimes 
dogged pursuit of entry points in mediation processes. These entry points are facilitated by direct contact and engagement with proscribed armed groups through back channelling, shuttling or through knowledge management workshops. This promotes the notion that the inclusion of these groups in a mediation process, under a certain set of conditions, may be better than their exclusion. By showing engagement is possible in practice, despite the ethical and moral, nongovernmental mediators display norm entrepreneurship.

The fragmented and highly complex nature ${ }^{11}$ of today’s conflicts (Fixdal 2015; Lanz 2017) have created new opportunities and possibilities for nongovernmental mediators to insert themselves into processes by engaging with proscribed armed groups. As previously explained, this revolution in diplomacy (Powell 2014) has resulted roles as facilitators or mediators instead of the UN or state governments. What could NGOs possibly have that powerful actors imbued with high levels of political legitimacy and capital do not? The answer lies directly in the debates around engaging with proscribed armed groups - nongovernmental mediators' main claim of value added lies in their ability to engage discretely with armed groups with the prospects of high gains and very low costs. Their main comparative advantage lies in their inherent disposability at low political risk if the process go awry, or as Oliver Richmond puts it, “provide a way of bypassing sovereignty and gaining internal access into societies,

${ }^{11}$ Some of these complexities include the high number of armed groups active in a given conflict context, conflicts that are internationalized through the geopolitics of the region, and the increasing number of mediation actors due to the professionalization of the field. 
economies and polities with a high degree of legitimacy and flexibility” (Richmond 2005, 23).

Engaging with proscribed armed groups were many nongovernmental mediators' entry point into the peacemaking field. Early examples of NGO involvement still straddled NGO’s traditionally virtuous roles of humanitarian aid providers buttressed by religious moral authority. For example, the most prominent early examples involved faith-based organizations such as the Quakers and the Vatican playing mediating roles. For example, the Community of Sant'Egidio's peacemaking role in Mozambique’s civil war between the governing FRELIMO and the rebel RENAMO (Mozambican National Resistance) since the country’s independence from Portugal in 1975. Early pioneers such as the HD Centre have actively brought this comparative advantage of talking to politically sensitive actors ${ }^{12}$ to the fore to carve out space in an increasingly crowded field of mediation actors (Lanz and Gasser 2013).While playing supportive and collaborative roles in the peace processes in Aceh and Nepal, the HD Centre "inserted themselves into the Basque conflict” with various amounts of skill as well as luck by presenting themselves to the Euskadi Ta Askatasuna (ETA) as the "next best thing” (Powell 2014) to a reluctant Swiss government. A growing number of nongovernmental organizations are either outfitted specifically with the flexibility to speak to politically sensitive armed groups such as the HD Centre or the Dialogue Advisory Group, or organizations headed by prominent political actors who formerly held formal positions such as former Senior Advisory to Tony Blair, Jonathan Powell’s Intermediate or former Finnish President and mediator Marrti Ahtisaari’s Crisis Management Initiative.

${ }^{12}$ Politically sensitive actors are such as these are not necessarily proscribed as terrorists. 
Mediators act within the parameters of their mandate givers. Mediators also have limited agency vis-à-vis negotiating parties, as they rely on the parties’ consent and acceptance of their intervention. Therefore, their agency is indicated by how they utilise their individual positions to carry out their intended action. Therefore, a mediator can be simultaneously an illiberal and liberal norm entrepreneur, depending on their mandate. UN Envoys are constrained by lists, but note that in certain contexts, engagement per se is not illegal under the UN proscription regime. Intergovernmental and governmental actors possess diplomatic immunity, this giving a feeling of protection and reliance on personal discretion and tacit member state approval (Haspeslaugh 2013). Furthermore, mediators mandated by different states have varying foreign policies, especially if one compares US or UK foreign policies with Norway and Switzerland. For example, Switzerland is not a member of the EU, but a member of the UN - this places Swissmandated mediators in a unique position to navigate the policies around proscription. Therefore, the parameters around proscription vary widely, as different mandate givers have different proscription regimes, laws, and lists. While mediators do have the intention to act and design strategies around the inclusion or exclusion of certain norms, they must do so in the parameters set out by their mandate giver, which clearly differ from one mandate giver to another.

In response to the changing conflict landscape characterised by the growing imperative to mediate outlined by the United Nations and its member states, the increase in ad hoc response to problems, and the growing imperative to speak to nonstate actors, the phenomenon of multi-party mediation has evolved over time. Multiple mediators working on a peace process, using their comparative advantages to play a variety of roles is a marked change over the last twenty years. Groups of Friends and Contact Groups (Whitfield 2010) have also become more heterogeneous in design. 
Initially comprised of different constellations of states under the auspices of the UN such as in El Salvador, East Timor, Georgia, Western Sahara, Southern Sudan and Syria inter alia others, the International Contact Group (Herbolzheimer and Leslie 2013; Herbolzheimer 2015) features four states and four nongovernmental organizations officially mandated to support the Malaysian facilitator in the negotiations between the Moro Islamic Liberation Front and the Government of the Philippines (2009-2014). In another example, the Office of the Special Envoy for Syria has also asked nongovernmental organizations such as swisspeace and NOREF Norwegian Centre for Conflict Resolution to support elements of the peace process concerning Syrian civil society ${ }^{13}$.

Multi-party mediation allows different types of mediation actors to use their respective comparative advantages and skill sets (Lanz, Sguaitamatti, and Siegfried 2009; Mason and Sguaitamatti 2011) particularly in regard to thorny issues surrounding engaging with proscribed armed groups. Those mediators who are restricted from engaging from individuals or groups proscribed on blacklists or terrorists lists often turn to nongovernmental organizations who have greater political flexibility and room for manoeuvre, despite the possible risks of possible criminalisation (Whitfield 2010; Haspeslagh 2013; Garrigues 2015). Therefore, when different types of mediators work together, the normative frameworks of mediation (“we talk to everyone”) and counterterrorism (“we don’t talk to terrorists”) become more fluid. The illiberal-liberal dichotomy has created this space against a backdrop of a shifting field: the days of the classical, singular mediator are effectively over.

\footnotetext{
${ }^{13}$ swisspeace, Syria (2017). Available at: http://www.swisspeace.ch/regions/syria.html
} (accessed 31 October 2017). 


\subsection{Consequence 2: The Liberal-Illiberal Dichotomy Reifies Dilemmas in}

\section{Mediation Practice}

Secondly, the liberal-illiberal dichotomy reifies dilemmas for mediators that do choose to engage with proscribed armed groups. While practices like multi-party and private mediation may strengthen the normative agency of mediators to manoeuvre between these clashing frameworks, this dichotomy also complicates things. Mediators who do choose engage with proscribed armed groups (exercising their normative agency) face dilemmas around how to include them. How can mediators include proscribed armed groups without excluding others? Is the inclusion of proscribed groups really inclusive or does it lead to the exclusion of other actors? The decision to engage with a group that has been deemed "terrorists" is a normatively loaded choice, and a mediation actor must decide how their inclusion or exclusion affects the outcome of a peace process. This dilemma is reified by the increasingly blurred line between the label of “terrorist and label as a “spoiler” in peace processes. Stedman’s (1997) seminal article argued that the greatest source of risk in peace processes comes from leaders or groups that perceive peace as threatening and use violence to undermine it (Nilsson and Söderberg Kovacs 2011). ${ }^{14}$ Heaven (2010) suggests that the concept of spoilers and derives its definition from assumptions about the liberal peacebuilding paradigm: actors that behave accordingly to this paradigm will be considered to raise fair and legitimate demands, whereas those who reject such a normative standard are viewed as spoilers, and since the events of 9/11 - labelled as terrorists rather than spoilers (Nilsson and

\footnotetext{
${ }^{14}$ The literature on spoilers and terrorism overlap as the war on terror has prompted studies on terrorist violence that occurs in the context of armed conflict or peace processes (see Kydd and Walter 2002; 2006; Braithewaite et al 2010).
} 
Söderberg Kovacs; Newman and Richmond 2006; Goodhand and Walton 2009; Zahar 2010).

This greatly complicates a mediator's normative agency. Scholarship on spoilers in peace process proffers a slew of suggestions on managing spoilers in peace processes ranging from inducement to coercion (Stedman 1997; Greenhill and Major 2007; Zahar 2010) - but the red thread that runs between them is engagement over non-engagement. In comparing three African peace processes in Mali, Western Sahara and Sudan, Blaydes and de Maio 2010) argue that peace process exclusivity (negotiations between only some of the parties to conflict) is more likely to breed violence than inclusive negotiations where are relevant groups are at the table. Zahar $(2016,47)$ posits that since parties inside a peace process are less likely to attempt to spoil it, mediators should attempt to consolidate insider loyalty to the process among antagonists that "refuses to eschew the difficult issues of truth, reconciliation, justice and accountability.”

A central element of a mediator's normative agency is the ability to interpret the environment around them (Wight 2006). This means they must take a normative stance on which actors are manifest or potential (Nilsson and Söderberg Kovacs 2011) spoilers, which actors are actually terrorists, and above all, which actors are relevant stakeholders. Despite the dizzying debates around the modalities of the inclusion or exclusion of proscribed armed groups, there is consensus around one thing: mediators promote the inclusion of the stakeholders that they deem relevant. For many mediators, this means engaging directly or including armed groups that may be illegal, indicted or proscribed as terrorists in peace talks (Whitfield 2010; Hellmüller, Palmiano Federer, and Zeller 2015; von Burg 2015; Garrigues 2015). 
This greatly complicates a mediator's normative agency. How does a mediator interpret a proscribed armed actor as terrorist/spoiler/relevant actor (or all three) in the context of this liberal-illiberal dichotomy? Furthermore, how can a mediator act based on his interpretation given his relatively low position of power vis-à-vis the parties as well as his mandate giver? Not only is the normative agency of mediators widely heterogeneous among their mandate-givers, but mediators themselves possess a normative framework distinct from their mandate-giver. This adds another layer of complexity: if the mandate-giver has an "illiberal mandate" barring the mediator from engaging with a proscribed armed group and promotes this norm of proscription, what does that mean for the mediator?

This is especially pertinent in the case of NGO mediators, who wield very little political and material power. As Toros (2008) suggests in her analysis of the armed conflicts in the Philippines, where the different armed actors are proscribed under varying national and international lists, dilemmas abound for mediators. While international prescription only applies to the CPP/NPA, alleged linkages and unclear ties and affiliations of the MNLF and the MILF to proscribed entities like Abu Sayyaf and Al Qaeda can make the legal and normative parameters around international engagement in peace processes complicated. While countries like the UK, Australia and many others have national law around listing terrorist organizations, all countries member to the EU or the UN must also comply to their restrictions. Therefore, perhaps with the exception of non-EU states like Norway and Switzerland ${ }^{15}$ with different foreign policies and different thresholds for engagement, the ramifications of conducting peacebuilding trainings, workshops and

\footnotetext{
${ }^{15}$ These countries would still prescribe to the parameters outlined by the UN and IHL.
} 
conferences may be political unsavoury even if they are legal under a given country's legal parameters.

\subsection{Consequence 3: Binary Thinking between Pragmatist and Normative} Approaches to Mediation

The dichotomy between liberal and illiberal creates binaries that obfuscates a

bigger normative challenge: whose peace is it (Liden 2005 etc) in the end and why does any challenge to liberal normative standards seen as illiberal (and negative)? If the views and needs of disputants that reject the liberal normative order (liberal state, liberal internationalism, liberal peacebuilding) are included in peace processes, does that automatically undermine the normative goal of peace? More specifically, does a mediator who aims to include proscribed actors who reject the liberal system, or what Zartman calls irreconcilables (ISIS, Taleban) an illiberal norm entrepreneur? This dichotomy creates a dangerous binaries between inclusion and exclusion and more generally, a binary between a normative and pragmatic approach to mediation. There can be a more graduated relationship between mediation and norms, and approaches to mediation need not take either a normative or pragmatic approach, between "clean” and "flexible" mediators. The Philippine peace process provides and illustrative point in this regard.

\section{Conclusion}

This paper aims to contribute to debates surrounding norm diffusion and the normative agency of mediation actors in mediation processes regarding norms that are perceived as illiberal or liberal. It examines whether their promotion of these norms renders them an illiberal or liberal norm entrepreneur, based on if and how they incorporate these norms into their overall mediation strategy. Due to the salience of the debate on whether and how mediation actors should 'talk to terrorists,' this paper focuses on two salient 
norms in mediation processes for mediators: the norm of inclusivity, manifested most prominently as engaging with all relevant groups in a given conflict context; and the norm of exclusivity, manifested in proscription regimes barring armed groups listed as terrorists from access to negotiations.

This paper argues that the liberal-illiberal dichotomy was created by the progressive norm bias in norm diffusion scholarship, and is rendered false when examining a mediator's normative agency in mediation processes. Norm diffusion models applied to mediation need adaptation to acknowledge the reality of contemporary mediation practice: the heterogeneity of mediators and the increasing popularity of multi-party mediation. The varied room for manoeuvre for mediators regarding exclusion and inclusion of armed groups in a mediation process render the illiberal-liberal distinction false and virtually unhelpful in studying a mediator's normative agency. The illiberal-liberal dichotomy may also lead to un-nuanced debates in policy and practice, especially in perilously contentious environment for discussing and understanding counter-terrorism initiatives and its nexus with peace mediation. Doing away with the illiberal-liberal dichotomy in norm diffusion scholarship opens up further avenues for research. While the dearth of theoretical work on 'illiberal norms,' or non-diffusion must be addressed, norms scholarship could greatly benefit from much more empirical work on how actors in international relations navigate illiberal norms. As the late 1990s and early 2000s produced a 'normative turn in social constructivism' that showcased ground-breaking empirical work on how norms affected international society, a revisit to this type of research with a more ambivalent view towards norms is sorely needed. 



\section{References}

ACCORD. 2015. Silencing the Guns: Terrorism, mediation and non-state armed groups. Windhoek: African Union High-level Retreat of Special Envoys and Mediators on the Promotion of Peace, Security and Stability in Africa.

Banlaoi, Rommel C. 2012a. Al Harakatul Al Islamiyyah: Essays on the Abu Sayyaf. Quezon City: Philippine Institute for Peace, Violence and Terrorism Research.

Banlaoi, Rommel C. 2012b. Quezon City. Current Terrorist Groups and Emerging Extremist Armed Movement in the Southern Philippines: Threats to Philippine National Security. Philippine Institute for Peace, Violence and Terrorism Research.

Bigo, Didier, and Anastassia Tsoukala. 2008. Terror, Insecurity and Liberty: Illiberal practices of liberal regimes after 9/11. Abingdon: Routledge.

Bloomfield, Alan. 2015. "Norm Antipreneurs and Theorising Resistance to Normative Change.” Review of International Studies 42 (2): 1-24. doi:

10.1017/S026021051500025X. Advance online publication.

Boon-Kuo, Louise, Ben Hayes, Vicki Sentas, and Gavin Sullivan. 2015. Building Peace in Permanent War: Terrorist Listing and Conflict Transformation. London: International State Crime Initiative and Transnational Institute.

Checkel, Jeffrey T. 1998. "Review: The Constructivist Turn in International Relations Theory." World Politics 50 (2): 324-348.

Convergne, Elodie. 2016. "Learning to Mediate? The Mediation Support Unit and the Production of Expertise by the UN." Journal of Intervention and Statebuilding 10 (2): 181-199. doi: 10.1080/17502977.2015.1079959.

Convergne, Elodie. 2016. "UN Mediators’ Collaboration with Scholars and Expert NGOs: Explaining the Need for Knowledge-Based Communities in Today’s Conflicts." International Negotiation 21 (1): 135-164. doi: 10.1163/15718069-12341327.

Crocker, Chester A., Fen Osler Hampson, and Pamela Aall. 2015. "The Shifting Sands of Peacemaking: Challenges of Multiparty Mediation." International Negotiation 20 (3): 363-388. doi: 10.1163/15718069-12341313.

Dudouet, Véronique. 2010. Mediating Peace with Proscribed Armed Groups. In Special Report. Washington, DC: United States Institute of Peace.

Dudouet, Véronique. 2011. Anti-Terrorism Legislation: Impediments to Conflict Transformation. Berghof Policy Brief. Berlin: Berghof Foundation.

Finnemore, Martha, and Kathryn Sikkink. 1998. "International Norm Dynamics and Political Change." International Organization 52 (4): 887-917. 
Fixdal, Mona. 2015. "The Minefields of Mediation: An Overview." International Negotiation 20: 353 - 362. doi: 10.1163/15718069-12341312.

Freeman, Samuel. 2001. "Illiberal Libertarians: Why Libertarianism is Not a Liberal View." Philosophy and Public Affairs 30 (2): 105-151.

Garrigues, Juan. 2015. The Case for Contact: Overcoming the Challenges and Dilemmas of Official and Non-Official Mediation with Armed Groups. Oslo: The Norwegian Resource Peacebuilding Centre.

Glennon, Michael. 2005. "How International Rules Die." Georgetown Law Journal 93 (3): 939-991.

Haspeslagh, Sophie. 2013. "'Listing terrorists": the impact of proscription on third party efforts to engage armed groups in peace processes - a practitioner s perspective." Critical Studies on Terrorism 6 (1): 189-208. doi: 10.1080/17539153.2013.765706.

Heller, Regina, and Martin Kahl. 2013. "Tracing and understanding "bad" norm dynamics in counterterrorism: the current debates in IR research." Critical Studies on Terrorism 6 (3):414-428. doi: 10.1080/17539153.2013.836305.

Hellmüller, Sara, Julia Palmiano Federer, and Mathias Zeller. 2015. The Role of Norms in International Peace Mediation. Bern: swisspeace.

Hellmüller, Sara, Julia Palmiano Federer, and Jamie Pring. 2017. Are Mediators Norm Entrepreneurs? Working Paper 3. Bern: swisspeace.

Herbolzheimer, Kristian. 2015. The peace process in Mindanao, the Philippines: Evolution and lessons learned. Oslo: The Norwegian Resource Peacebuilding Centre.

Herbolzheimer, Kristian, and Emma Leslie. 2013. Innovation in mediation support: The International Contact Group in Mindanao. Practice Paper. London: Conciliation Resources.

Kastner, Philipp. 2015. Legal Normativity in the Resolution of Internal Armed Conflict. Cambridge: Cambridge University Press.

Keck, Margaret E., and Kathryn Sikkink. 1998. Activists Beyond Borders: Advocacy Networks in International Politics. Ithaca: Cornell University Press.

Klotz, Audie. 1995. "Norms Reconstituting Interests: Global Racial Equality and U.S. Sanctions Against South Africa." International Organization 49 (3): 451-478.

Lanz, David. 2011. "Who Gets a Seat at the Table? A Framework for Understanding the Dynamics of Inclusion and Exclusion in Peace Negotiations." International Negotiation 16 (2): 275-295. doi: 10.1163/138234011x573048. 
Lanz, David, Damiano Sguaitamatti, and Matthias Siegfried. 2009. Towards Realizing the Strengths and Mitigating the Challenges of NGO Mediators. Mediation Support Project. Bern: swisspeace and the Center for Security Studies ETH.

Lidén, Kristoffer. 2006. "Whose Peace? Which Peace? On the Political Architecture of Liberal Peacebuilding." In Institute IPR (ed). Oslo: International Peace Research Institute. Loesch, Juliette. 2017. "The GPH-MILF Peace Process in the Philippines to Prevent and Transform Violent Extremism in Mindanao." Journal of Peacebuilding \& Development 12 (2): 96-101. doi: 10.1080/15423166.2017.1331747.

Mason, Simon. 2009. Insider Mediators: Exploring Their Key Role in Informal Peace

Processes. Zurich: Center for Security Studies ETH, swisspeace, and the Berghof Foundation.

Mason, Simon, and Damiano Sguaitamatti. 2011. "Mapping Mediators: A comparison of third parties and implications for Switzerland." Zurich: Center for Security Studies ETH. McKeown, Ryder. 2009. "Norm Regress: US Revisionism and the Slow Death of the Torture Norm." International Relations 23 (1): 5-25.

Muller, Mark, QC. 2008. "Terrorism, Proscription, and the Right to Resist in the Age of Conflict." Denning Law Journal 20: 11 - 131.

Nadelmann, Ethan A. 1990. "Global Prohibition Regimes: The Evolution of Norms in International Society." International Organization 44 (4): 479-526.

Newman, Edward, Roland Paris, and Oliver P. Richmond. 2009. New Perspectives on Liberal Peacebuilding. Tokyo: United Nations University Press.

Paffenholz, Thania. 2004. Designing Transformation and Intervention Processes. Berghof Handbook. Berlin: Berghof Foundation.

Paris, Roland. 2002. "International Peacebuilding and the 'Mission Civilisatrice'." Review of International Studies 28: 637-656.

Powell, Jonathan. 2014. Talking to Terrorists: How to End Armed Conflicts. New York: Random House.

Price, Richard. 1998. "International norms and the mines taboo: Pulls toward compliance." Canadian Foreign Policy Journal 5 (3): 105-123.

Richmond, Oliver P. 2012. "Beyond Local Ownership in the Architecture of International Peacebuilding." Ethnopolitics: Formerly Global Review of Ethnopolitics 11: 354-375

Risse-Kappen, Thomas, and Kathryn Sikkink. 1999. "The Socialization of International Human Rights Norms into Domestic Practices: Introduction." In The Power of Human Rights: 
International Norms and Domestic Change, edited by Thomas Risse-Kappen, Stephen

C. Ropp and Kathryn Sikkink. New York: Cambridge University Press.

Sullivan, Gavin, and Ben Hayes. 2010. Blacklisted: Targeted Sanctions, Pre-emptive Security, and Fundamental Rights. In 10 Years after 9/11 Publication Series. Berlin: European Center for Constitutional and Human Rights.

Tannenwald, Nina. 1999. "The Nuclear Taboo: The United States and the Normative Basis of Nuclear Non-Use." International Organization 53 (3): 433-468.

Toros, H. 2008. "'We Don't Negotiate with Terrorists!' Legitimacy and Complexity in Terrorist Conflicts." Security Dialogue 39 (4): 407-426. doi: 10.1177/0967010608094035.

Triadafilopoulos, Triadafilo. 2011. "Illiberal Means to Liberal Ends? Understanding Recent Immigration Integration Policies in Europe." Journal of Ethnic and Migration Studies 37 (6):861-880. doi: 10.1080/1369183X.2011.576189.

United Nations. 2012. UN Guidance for Effective Mediation. New York: United Nations.

von Burg, Corinne. 2015. On Inclusivity: The Role of Norms in International Peace Mediation. Bern: swisspeace.

Wanis St-John, Anthony, and Darren Kew. 2008. "Civil Society and Peace Negotiations: Confronting Exclusion." International Negotiation 13:11-36.

Whitfield, Teresa. 2010. External Actors in Mediation - Dilemmas and Options for Mediators. Geneva: Centre for Humanitarian Dialogue.

Zakaria, Fareed. 1997. "The Rise of Illiberal Democracy." Foreign Affairs.

Zanker, Franzisca. 2014. "Legitimate Representation: Civil Society Actors in Peace Negotiations Revisited." International Negotiation 19: 62-88. doi: 10.1163/15718069-12341270.

Zartman, William I. 2008. Negotiation and Conflict Management: Essays on Theory and Practice: Abingdon: Routledge. 